\title{
Nutritional Quality and Functional Properties of Baobab (Adansonia digitata) Pulp from Tanzania
}

\author{
Angela Aluko ${ }^{1,3}$, John Kinyuru ${ }^{1}$, Lucy Mlipano Chove ${ }^{2}$, Peter Kahenya ${ }^{1} \&$ Willis Owino ${ }^{1}$ \\ ${ }^{1}$ Jomo Kenyatta University of Agriculture and Technology, Department of Food Science and Technology, P. O. \\ Box 62000-00200, Nairobi, Kenya \\ ${ }^{2}$ Sokoine University of Agriculture, Department of Food Technology,Nutrition and Consumer Sciences P. O. Box \\ 3006,CHUO KIKUU, Morogoro, Tanzania \\ ${ }^{3}$ Mbeya University of Science and Technology, Department of Science and Business Management, P. O. Box 131, \\ Mbeya, Tanzania \\ Correspondence: Angela Aluko, Jomo Kenyatta University of Agriculture and Technology, Department of Food \\ Science and Technology, P. O. Box 62000-00200, Nairobi, Kenya. E-mail: angelaluko2005@yahoo.com
}

Received: July 25, 2016 Accepted: August 16, $2016 \quad$ Online Published: September 27, 2016

doi:10.5539/jfr.v5n5p23 URL: http://dx.doi.org/10.5539/jfr.v5n5p23

\begin{abstract}
Baobab (Adansonia digitata L.) is a majestic tree associated with human habitation in some of the semi-arid regions of Africa and establishes an enormous economic and nutritional importance to the rural residential districts. The fruit pulp is considered to be of high nutritional significance; particularly vitamin $\mathrm{C}$ and calcium, also possess antioxidant functions as well as high dietary fiber content. Although it is a potential fruit for improving local diets and livelihoods,this fruit is underutilized and its potential not yet fully acknowledged. This work was contracted with the aim of defining the nutritional quality and functional properties of baobab pulp harvested from some selected parts of Tanzania.

Results indicated that the pulp from the three locations had moisture content which ranged between $9.16 \%$ to $10.30 \%$, fat $0.46 \%-1.98 \%$, ash $4.75 \%-5.21 \%$, fiber $5.91 \%-9.65 \%$, protein $3.23 \%-3.53 \%$, carbohydrate $80.49 \%-85.19$, vitamin C $169.74 \mathrm{mg} / 100 \mathrm{~g}-231.57 \mathrm{mg} / 100 \mathrm{~g}$, beta-carotene $2.16 \mathrm{mg} / 100 \mathrm{~g}-3.19 \mathrm{mg} / 100 \mathrm{~g}$.Fructose $0.56 \pm 0.15-0.81 \pm 0.17 \mathrm{~g} / 100 \mathrm{~g}$, glucose $0.77 \pm 0.26-0.87 \pm 0.31 \mathrm{~g} / 100 \mathrm{~g}$ and sucrose $0.75 \pm 0.25-0.84 \pm 0.29 \mathrm{~g} / 100 \mathrm{~g}$. The substantial differences $(\mathrm{p} \leq 0.05)$ between locations were observed in fat, crude fiber, carbohydrates, and fructose. Vitamin C, beta-carotene, protein, ash, moisture, sucrose and glucose showed no significance difference $(p \leq 0.05)$ among locations. The functional properties included emulsification, foaming and gelling properties which ranged between $37.9-45.15 \%, 1.85-6.57 \%$ and $11-12 \%$ respectively and were significantly different $(p \leq 0.05)$ among locations. The results show that baobab pulp has a good content of nutrients and functional properties which can be useful in food industries.
\end{abstract}

Keywords: Adansonia digitata, Baobab pulp, functional property, nutritional quality

\section{Introduction}

The Baobab (Adansonia digitata) belongs to the Bombacaceae family which comprises of around 20 genera and 180 species including closely interrelated species such as Adansonia gregori and Adanosnia madagascariensi (Kamatou et al .,2011, Mulani \& Kharate,2015), also known as the "upside down tree”, on pollination by fruit bats, it produces big green or brownish fruits which are capsules and naturally indehiscent. The capsules have a soft whitish powdery pulp and kidney shaped seeds (Sidibe \& Williams, 2002).

The baobab is an important indigenous fruit tree throughout the dry lands of Africa, in Malaysia, China, Jamaica and Australia (Jamal et al., 2005). Several studies in Benin, Burkina Faso, Malawi, Mali, Nigeria, Tanzania and South Africa have emphasized this deciduous stem-succulent taxon as precedence species for domestication and increased its consumption (Lamien-Meda et al., 2008). The baobab fruit is also used in the day-to-day diet of rural societies in Africa (Assogbadjo et al., 2008a, Ibrahima et al., 2013). The species contribute to rural revenues ( $\mathrm{Kamatou}$ et al.,2011) and has several essential food and medicinal uses (Kaboré et al., 2011); the pulp is mostly consumed traditionally in different forms. It is also used in the preparation and formulation of cereals and beverages. 
Although, baobabs are extensively recognized, the present scientific information on the biochemistry and significance of its fruit in human nutrition is inadequate. Up to the present time, most of the studies have focused on A. digitata in relative to its agronomical, botanical and biochemical characteristics (Gebauer et al.,2002).

It was reported that baobab is a nutrient rich fruit which has ascorbic acid, riboflavin, niacin, pectin and citric, malic and succinic acids, while the oil also comprises the vitamins D, E and A (Besco et al.,2007, Donkor et al., 2014). The pulp of A. digitata is a $1 \mathrm{~s}$ o rich in dietary fibers (Ibrahima et al.,2013). The soluble fibers of baobab fruit pulp are prebiotics: non-digestible food components that beneficially affect the host by selectively stimulating the growth and/or activity of beneficial microflora,hence supporting probiotics,(Gruenwald \& Galizia,2005).

The objective of this study was to determine the chemical composition and functional characteristics of the baobab fruit pulp from a specific geographical location in Tanzania.

\section{Material and Methods}

\subsection{Acquisition of Baobab Fruits}

The baobab fruit samples were collected from Arusha, Makuyuni areas from three locations including Naitolia camp, Kwa Muhindi and Oldonyo Orng'ina. Baobab fruit were harvested from three trees per each location. The Criteria used for selecting the trees to be sampled from were trunk which was cylindrical tapering shape and leaf shape .The fruits were collected during September, 2015, and at that time the trees had already shed the leaves and hence so only the trunk shape was used as the harvesting criteria.

\subsection{Sample Preparation}

\subsubsection{Preparation of Baobab Pulp and Yield}

Whole baobab fruits were weighed, and their hard woody shells were carefully crushed and the pulp was separated from the seeds, grounded using pestle and mortar to separate the pulp from the seeds. The mixture was sieved using a 0.09 micron sieve to obtain a fine powder. The powder was weighed and instantly packed into polyethylene bags sealed and stored in a dark cool place. This procedure is shown in figure 1.

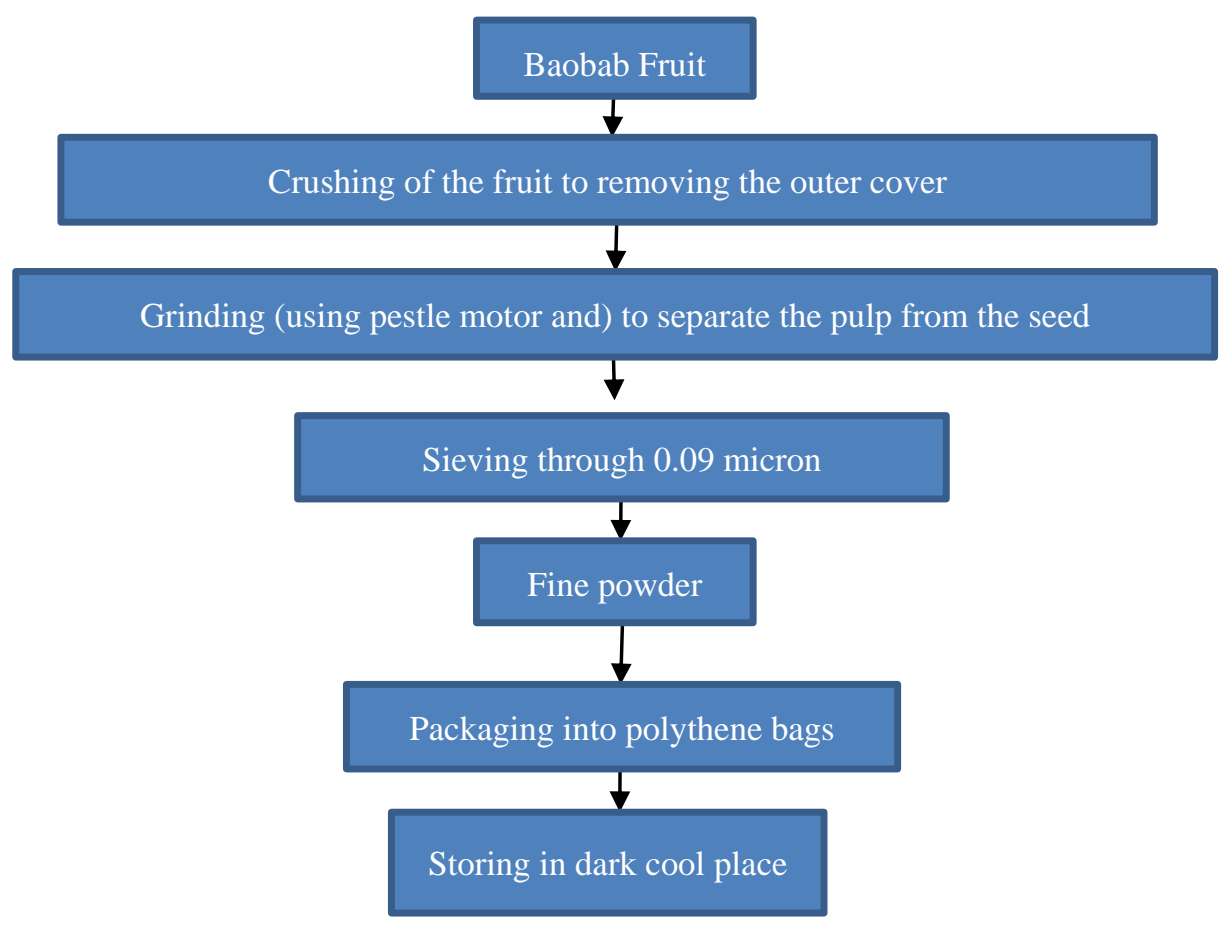

\subsection{Proximate Composition}

Figure 1. Flow chart of baobab pulp production

The protein, crude-fibre, ash, fat and moisture were determined using the method of Association of Official Analytical Chemists (AOAC, 2003). 


\subsection{Sugars}

Ten grams of ground homogenous sample was mixed with $50 \mathrm{ml}$ of $96 \%$ ethyl alcohol. The mixture was refluxed at $100^{\circ} \mathrm{C}$ for 1 hour and the slurry filtered. The filtrate was evaporated to dryness at $60^{\circ} \mathrm{C}$ and dissolved in $10 \mathrm{ml}$ distilled water. Two $\mathrm{ml}$ of the solution was mixed with $2 \mathrm{ml}$ of acetonitrile and filtered through $0.45 \mu \mathrm{m}$, (AOAC, 2003). Then $20 \mu \mathrm{l}$ was injected into Higher Performance Liquid Chromatography (HPLC) -Shimadzu 20 A Series, with amide column - $\mathrm{NH}_{2}$-LUNA-100A (250X4.6mm), Diameter $-5 \mu 1$ and Refractive Index Detector.

\subsection{Determination of $\beta$-Carotene}

About $5 \mathrm{~g}$ of the sample was weighed accurately, and extraction was done using $40 \mathrm{ml}$ of petroleum ether and $30 \mathrm{ml}$ acetone. The mixtures were put in a separating funnel. Distilled water was added slowly along the neck of separating funnel without shaking to avoid emulsion formation. The two phases were then left to separate and the lower aqueous layer discarded. The sample was washed $3-4$ times with $200 \mathrm{ml}$ distilled water each time to remove residual acetone. In the last phase, washing was done ensuring that no amount of the upper phase was discarded. Then, the upper layer was collected into $50 \mathrm{ml}$ flask using anhydrous sodium sulphate filter arrangement to remove residual water, (AOAC, 2003). The absorbance was determined at $450 \mathrm{~nm}$ using UV-visible spectrophotometer (Shimadzu -UV 1800).The concentration of beta carotene was calculated undard curve.

\subsection{Determination of Vitamin C}

Vitamin $\mathrm{C}$ was done according to the method described by (Vikram et al .,2005). Basically $1 \mathrm{~g}$ of the sample was mixed with metaphosphoric acid and centrifuged at $10,000 \mathrm{rpm}$ for 10 minutes at $4^{\circ} \mathrm{C}$ in a refrigerated centrifuge (Model H-2000C). The supernatant was sieved through whatman No 4 filter paper. The filtrate was diluted with $1 \mathrm{ml}$ of $0.8 \%$ metaphosphoric acid and filtered with 0.450 Millipore filter and $20 \mu \mathrm{l}$ of the sample injected into the HPLC(Shimadzu 20 A Series, with column - $\mathrm{NH}_{2}$-LUNA-100A (250X4.6mm), Diameter -5ul and Refractive Index Detector.

\subsection{Functional Properties of Baobab Pulp Powder}

\subsubsection{Foaming}

Two grams of baobab powder were dissolved in $100 \mathrm{ml}$ of distilled water and blended at high speed for 1 minutes. The volume of the mixture was measured. The foaming capacity was calculated as the volume of the mixture after blending compared to the original volume (Santana et al., 2012). The formula used for calculation was:

$$
\text { Foaming capacity }=\frac{v 2-v 1}{v 1} * 100
$$

Where: v1=Initial volume

$\mathrm{V} 2$ = Final volume

\subsubsection{Gelation}

Baobab powder sample suspension of $10-15 \%$ was prepared in distilled water and vortexed in a vortex (model TM.151) for 5 minutes.Ten milliliter of each prepared dispersion was transferred into a test tube. The tubes were heated in water bath (model SHA-C) at $90^{\circ} \mathrm{C}$ for 30 minutes and then placed in a cold room at $4^{\circ} \mathrm{C}$ for 30 minutes. The gelation concentration was determined as the lowest concentration at which the sample did not fall down or slip from an inverted test tube (Santana et al., 2012).

\subsubsection{Emulsification}

A $5 \mathrm{~g}$ baobab powder sample was dissolved in $20 \mathrm{ml}$ of distilled water, mixed with $20 \mathrm{ml}$ of corn oil, blended for 1 minute and centrifuged at $7500 \mathrm{rpm}$ for 5 minutes (Santana et al., 2012). The formula used for calculation was:

$$
\text { Emulsification capacity }=\frac{\text { Volume after homogenization-Volume after centrifugation }}{\text { Volume after homogenization }} \times 100
$$

\subsection{Data Analysis}

All physicochemical results was reported in mean \pm standard deviation (SD). Differences were determined by Analysis Of Variance (ANOVA) and the means separated by Least Significance square (LSD) using SPSS version 20 software. 


\section{Result and Discussion}

\subsection{Baobab Pulp Yield}

The mean weight of baobab fruits were 4465g, 2635g and 4020g for Naitolia camp, Kwa muhindi and Oldonyo Orng'ina respectively. The yields for baobab pulp were $285 \mathrm{~g}$ (6\%) for Naitolia camp, $200 \mathrm{~g}(7.6 \%)$ for Kwa muhindi and $320 \mathrm{~g}(7.9 \%)$ for Oldonyo Orng'ina, as stipulated on table 1.

Table 1. Baobab pulp yield

\begin{tabular}{llll}
\hline Location & Weight of baobab fruits $(\mathrm{g})$ & Baobab pulp yield $(\mathrm{g})$ & \% yield of baobab pulp \\
\hline Kwa muhindi & 2635 & 200 & 7.6 \\
Naitolia camp & 4465 & 285 & 6 \\
Oldonyo Orng'ina & 4020 & 320 & 7.9 \\
\hline
\end{tabular}

\subsection{Proximate Composition}

Moisture content for baobab pulp was found to be $9.94 \pm 0.54 \%$ for Kwa muhindi location, $10.30 \pm 1.28 \%$ for Naitolia camp, $9.55 \pm 0.22 \%$ and $9.16 \pm 1.15 \%$ for Oldonyo Orng'ina respectively as indicated in table 2 .The outcomes revealed no significance difference at $(\mathrm{P} \leq 0.05)$. Moisture content of baobab pulp from Naitolia camp were higher than the value range of 7.87\%-8.59\% reported by (Abdalla et al., 2010).However, (Osman ,2004) reported $10.4 \%$ which is higher compared to all three locations.

Baobab pulp in this study contained crude fat value of $1.98 \pm 0.69 \%, 1.11 \pm 0.35 \%$ and $0.46 \pm 0.13 \%$ for Kwa muhindi, Naitolia camp and Oldonyo Orng'ina respectively. Significant differences were observed among the three locations $(\mathrm{P} \leq 0.05)$. Present findings were noticeably higher compared to the value of $0.3 \%$ reported by (Osman, 2004), 0.2\% (Abdulkarim et al., 2014) and for 1.43\% (Abdalla et al., 2010).

Ash content was $5.21 \pm 0.39 \%, 4.87 \pm 0.51 \%$ and $4.75 \pm 0.51 \%$ for Naitolia camp, Kwa muhindi and Oldonyo Orng'ina samples, respectively. Results indicated that there is no significant difference $(P \leq 0.05)$ as shown in table 2. Present findings for the locations were within the range as reported value of $4.5 \%$ stated by (Osman, 2004) and 5.5\% (Magaia etal ; 2013b).,but lower for both location as reported value of 5.8\% (Sidibe \& Williams, 2002).

As shown in Table (2), pulp collected from Kwa muhindi, Naitolia camp and Oldonyo Orng'ina was found to contain sequentially $6.29 \pm 2.57 \%, 9.65 \pm 0.36 \%$ and $5.91 \pm 1.42 \%$ crude fiber. Data showed that the three locations were significantly different $(\mathrm{P} \leq 0.05)$. These results were comparable to those reported by (Sidibe $\&$ Williams, 2002) and Caluwé \& Damme, 2010; ) which ranged between 5.4 and $11.5 \%$.

Protein content of baobab fruit pulp was found to be $3.53 \pm 0.29 \%, 3.23 \pm 0.23 \%$ and $3.52 \pm 0.27 \%$ for Naitolia camp, Kwa Muhindi and Oldonyo Orng'ina, respectively with no significant difference ( $\mathrm{P} \leq 0.05)$ between the three locations. Results reported were within the range of 2.5-17\% obtained by (Ibrahima et al., 2013) and (Sidibe \& Williams, 2002), but higher than the 2.1-2.4\% concentration reported by (Gebauer et al.,2002) and (Magaia et al., 2012a), respectively.

The carbohydrate content of the baobab pulp was $80.49 \pm 0.48 \%, 83.58 \pm 2.77 \%$ and $85.19 \pm 1.53 \%$ for Naitolia camp, Kwa Muhindi and Oldonyo Orng'ina, respectively. Samples from Oldonyo Orng'ina showed significantly higher content for carbohydrate $(\mathrm{P} \leq 0.05)$ than the remaining two sites. Data obtained were within the range compared with 73.7 to $81 \%$ previously reported by (Osman, 2004), (Abdalla et al., 2010,) and (Rahul et al.,2015).

The variation for the proximate results may be due to, the provenance of the sample, the treatment before analysis, the storage environments, the processing techniques, a probable genetic variation,ripening age difference (Fagbohun et al.,2012) and physical chemical characteristics of the soil (Assogbadjo et al.,2012b,Fagbohun et al.,2012).Apart from the variability in the material, the analytical methods and inherent variability may also be a cause of variability.

In general, these results reveal that baobab pulp is rich in carbohydrate, ash but low in moisture and fat content.This is an important finding which indicates that it can be kept for a period of time before going bad. 
Table 2. Proximate for baobab pulp

\begin{tabular}{lllllll}
\hline Location & Moisture $(\%)$ & Fat $(\%)$ & $\%$ Ash $(\%)$ & Crude fiber(\%) & Protein(\%) & Carbohydrate (\%) \\
\hline Kwa Muhindi & $9.94 \pm 0.54^{\mathrm{a}}$ & $1.98 \pm 0.69^{\mathrm{a}}$ & $4.87 \pm 0.51^{\mathrm{a}}$ & $6.29 \pm 2.57^{\mathrm{a}}$ & $3.23 \pm 0.23^{\mathrm{a}}$ & $83.58 \pm 2.77^{\mathrm{a}}$ \\
Naitolia camp & $10.30 \pm 1.28^{\mathrm{a}}$ & $1.11 \pm 0.35^{\mathrm{b}}$ & $5.21 \pm 0.39^{\mathrm{a}}$ & $9.65 \pm 0.36^{\mathrm{b}}$ & $3.53 \pm 0.29^{\mathrm{b}}$ & $80.49 \pm 0.48^{\mathrm{b}}$ \\
Oldonyo Orng'ina & $9.16 \pm 1.15^{\mathrm{b}}$ & $0.46 \pm 0.13^{\mathrm{c}}$ & $4.75 \pm 0.51^{\mathrm{b}}$ & $5.91 \pm 1.42^{\mathrm{a}, \mathrm{c}}$ & $3.52 \pm 0.27^{\mathrm{b}, \mathrm{c}}$ & $85.19 \pm 1.53^{\mathrm{a}, \mathrm{c}}$ \\
P value & 0.08 & 0.00 & 0.11 & 0.00 & 0.38 & 0.00 \\
LSD & 0.36 & 0.64 & 0.11 & 0.38 & 0.29 & 1.61 \\
\hline
\end{tabular}

Each value in average of three replicates

Values are Mean \pm Standard deviation

Means in the same column followed by the same superscript are not significantly different at $\mathrm{p}<0.05$.

\subsection{Ascorbic Acid (Vitamin C) and Beta Carotene Content}

As presented in table 3, pulp obtained from baobab fruit from Kwa muhindi location had the maximum ascorbic acid content $231.57 \pm 140.41 \mathrm{mg} / 100 \mathrm{~g}$ followed by Oldonyo Oring'ina $211.99 \pm 84.82 \mathrm{mg} / 100 \mathrm{~g}$ ), whereas that from Naitolia camp revealed the lowermost vitamin C level $(169.74 \pm 85.43 \mathrm{mg} / 100 \mathrm{~g})$, a n d th e o u t c o m e s s h ow ed no significant difference $(\mathrm{P} \leq 0.05)$. The content are higher compared with $34-200 \mathrm{mg} / 100 \mathrm{~g}$ reported by( Sidibe \& Williams ,2002), and lower with content of $300 \mathrm{mg} / 100 \mathrm{~g}$ and $355.7 \mathrm{mg} / 100 \mathrm{~g}$,reported by (Gebauer et al.,2002) and (Almustafa ,2003) respectively.

The high values of ascorbic acid in baobab pulp imply the potential use of the fruit as a good antioxidant. The recommended daily intake (RDI) of ascorbic acid is about $30 \mathrm{mg} /$ day for adults and $17 \mathrm{mg} / \mathrm{day}$ for children(Othman et al., 2014). Consequently, these fruits could be well-thought-out as good sources of ascorbic acid for purposes of human nutrition.

Beta carotene was found to be $2.16 \pm 1.77 \mathrm{mg} / 100 \mathrm{~g}, 3.03 \pm 1.79 \mathrm{mg} / 100 \mathrm{~g}$ and $3.19 \pm 1.68 \mathrm{mg} / 100 \mathrm{~g}$ for Kwa Muhindi, Naitolia camp and Oldonyo Orng'ina raw pulp respectively. Oldonyo Orng'ina sample showed higher beta carotene content compared with those from Naitolia camp and Kwa muhindi. In this research, the results indicated no significance difference $(\mathrm{P} \leq 0.05)$ in beta-carotene content between the three locations.

Moreover, micronutrients, such as minerals and vitamins, are biologically active. They can interact with other nutrients and change in their bioavailability, hence it may be also a contributing factor for variation(Caluwé \& Damme, 2010),in addition to the previously mentioned factors under proximate variation.

Table 3. Vitamin C, Beta- carotene and for baobab pulp

\begin{tabular}{lll}
\hline Location & VitaminC $(\mathrm{mg} / 100 \mathrm{~g})$ & Beta carotene $(\mathrm{mg} / 100 \mathrm{~g})$ \\
\hline Kwa Muhindi & $231.57 \pm 140.41^{\mathrm{a}}$ & $2.16 \pm 1.77^{\mathrm{a}}$ \\
Naitolia camp & $169.74 \pm 85.43^{\mathrm{a}}$ & $3.03 \pm 1.79^{\mathrm{a}}$ \\
Oldonyo Orng'ina & $211.99 \pm 84.82^{\mathrm{a}}$ & $3.19 \pm 1.68^{\mathrm{a}}$ \\
P value & 0.47 & 0.42 \\
LSD & 19.57 & 0.16 \\
\hline
\end{tabular}

Each value in average of three replicates

Values are Mean \pm Standard deviation

Means in the same column followed by the same superscript are not significantly different at $\mathrm{p}<0.05$.

\subsection{Sugars}

Sugars tested were glucose, fructose and sucrose and the results are stipulated in table 4.Fructose was high in Naitolia camp while glucose and sucrose was high in Kwa muhindi locations. The simple sugar values ranged as follows: fructose $0.56 \pm 0.15-0.81 \pm 0.17 \mathrm{~g} / 100 \mathrm{~g}$,glucose $0.77 \pm 0.26-0.87 \pm 0.31 \mathrm{~g} / 100 \mathrm{~g}$ and sucrose $0.75 \pm 0.25-0.84 \pm 0.29 \mathrm{~g} / 100 \mathrm{~g}$ for Naitolia camp, Kwa muhindi and Oldonyo Orng'ina locations. One study reported glucose, fructose and sucrose to be $7.9 \mathrm{~g} / 100 \mathrm{~g}$ and $7.0 \mathrm{~g} / 100 \mathrm{~g} 1.7 \mathrm{~g} / 100$ respectively (Ibrahima et al., 2013).The results for sucrose were lower whereas glucose and fructose were higher than the values reported by Ibrahim et al., (2013) The results show there is significance difference at $(\mathrm{P} \leq 0.05)$ for fructose while no significance for sucrose and lactose among the location. Fructose, sucrose and glucose contribute to the pulp sweetness ( Caluwé \& Damme, 2010, Namratha \& Sahithi, 2015). 
Table 4. Sugar content for baobab pulp

\begin{tabular}{llll}
\hline Location & Fructose $(\mathrm{g} / 100 \mathrm{~g})$ & Glucose $(\mathrm{g} / 100 \mathrm{~g})$ & Sucrose $(\mathrm{g} / 100 \mathrm{~g})$ \\
\hline Kwa Muhindi & $0.62 \pm 0.17^{\mathrm{a}}$ & $0.87 \pm 0.31^{\mathrm{a}}$ & $0.84 \pm 0.29^{\mathrm{a}}$ \\
Naitolia camp & $0.81 \pm 0.17^{\mathrm{b}}$ & $0.81 \pm 0.24^{\mathrm{a}}$ & $0.79 \pm 0.23^{\mathrm{a}}$ \\
Oldonyo Orng'ina & $0.56 \pm 0.15^{\mathrm{c}}$ & $0.77 \pm 0.26^{\mathrm{a}}$ & $0.75 \pm 0.25^{\mathrm{a}}$ \\
P value & 0.01 & 0.76 & 0.76 \\
LSD & 0.05 & 0.04 & 0.04 \\
\hline
\end{tabular}

Each value in average of three replicates

Values are Mean \pm Standard deviation

Means in the same column followed by the same superscript are not significantly different at $\mathrm{p}<0.05$.

\subsection{Gelation}

The lowest concentration at which the sample does not fall down/slip from an overturned test tube was used as index of gelation capacity. The lower the Lowest Gelation Concentration(LGC), the superior the gelatin capacity of the protein ingredient (Atta \& El-Shenawi, 2013). As shown in figure 1 a good gel was formed at $11 \%(\mathrm{w} / \mathrm{v})$ which is within the range as similar to (Eltayeb,et al., 2011), 8\%-18\%. The lower the Lowest Gelation Concentration( LGC), the better the gelatin ability of the protein ingredient (Atta \& El-Shenawi, 2013). The low LGC observed in the baobab pulp may be advantage in respect to the production of some products such as curd since production of such, requires ingredients with high gelation capacity like milk protein(casein) (Kisambira, et al., 2015), and in jam making due to higher content of pectin which contribute to the excellent gelling capacity (Ndabikunze, et al., 2011).

\subsubsection{Foaming Capacity}

In this study, low foaming capacity was found from the baobab pulp powder of Kwa Muhindi location with a value of $1.85 \%$. While the highest foaming capacity was from Naitolia camp location which had a value of $6.57 \%$, with significance difference at $(\mathrm{P} \leq 0.05)$, as presented in figure 1 . In comparison with baobab pulp mixed with ogi flour (Adejuyitan, et al.,2012) ranged 3.2-11.7 \%, which is within for Naitolia camp. Baobab pulp powder tends to have a lower foaming capacity in comparison with egg yolk powder which is commonly used for its exceptional foaming capacity having a value of $38.50 \%$ (Ndife,et al.,2010). In comparison with other fruits like watermelon seed flour, the value are lower as reported by (Oyeleke et al.,2012) with $23.5 \%$ and higher compared to the dehulled and cooked jackbean flour which is $0.02 \%$, Obiageli, 2005). In regard with these results, use of baobab pulp powder for foaming application may therefore, not be ideal as my require further modification.

\subsubsection{Emulsification}

As shown in Figure 2, the highest emulsion of baobab pulp powder was reported on Oldonyo Orng'ina location with value of $45.15 \%$ and the lowest was on Naitolia camp $37.90 \%$, with significance difference at $(\mathrm{P} \leq 0.05)$. This results revealed that baobab pulp powder had almost half emulsification capacity,74\% (Ndife et al.,2010), the emulsification properties of egg york powder one of the first-rate emulsifiers. In comparison with other fruits, it has slightly similar value with yam bean flour $35.70 \%$ (Kisambira et al.,2015) for Naitolia camp but higher for Kwa muhindi and Oldonyo Orng'ina,and higher compare to jack fruit flour 2.53-3.16\% reported by (Obiageli ,2005) for both locations. According to this result, the use of baobab pulp powder for emulsification application may not be ideal and require further modification. 


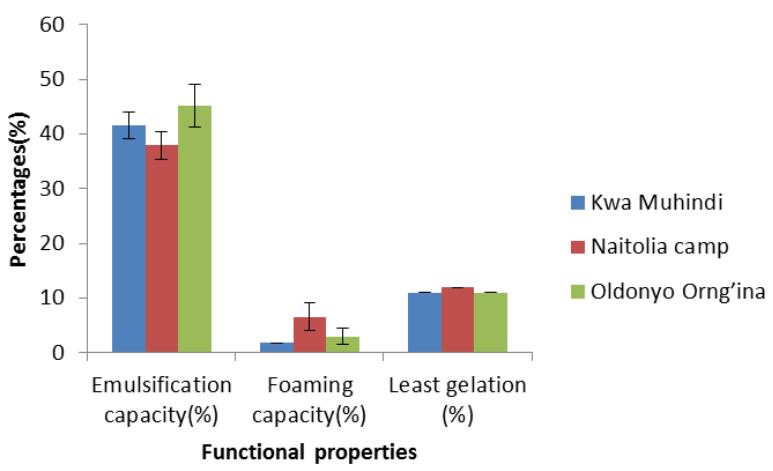

Figure 2. Functional properties of baobab pulp

\section{Conclusion}

The major findings in this research indicated that baobab (Adansonia digitata) pulp had low fat and protein content. The pulp also had low fat and moisture contents, indicating that it had good keeping qualities. It is also a good source of macronutrients, specially carbohydrate, crude fiber and micronutrients especially Vitamin $\mathrm{C}$ and beta-carotene. This could be useful in value addition and product development hence promoting the use of non-timber forest products. Functional properties for baobab pulp indicates can be used for various food products companies in recipe development, as it has good gelation properties which is a significant attribute for food processing.

\section{Acknowledgments}

The authors are grateful to the, innovative Agricultural Research Inniative (iAGRI), Regional Universities Forum for Capacity Building in Agriculture (RUFORUM) and sub grant from the "Fruiting Africa" project funded by International Fund for Agricultural Development (IFAD) through the International Centre for Research in Agroforestry (ICRAF) and for the financial support.

\section{References}

AOAC. (2003). Official methods of analysis of the association of official's analytical chemists, 17th edn. Association of official analytical chemists, Arlington, Virginia.

Abdalla, A. A, Mohammed M. A., \& Mudawi, H. A. (2010). Production and Quality Assessment of Instant Baobab (Adansonia digitata L .). Advanced Journal of Food Science and Technology, 2(2), 125-133.

Abdulkarim, S. M, Bamalli, Z, G. M., \& K. R. (2014). Baobab Tree ( Adansonia digitata L ) Parts : Nutrition , Applications in Food and Uses in Ethno-medicine - A Review. Annals of Nutrition Disorders and Therapy, l(3), 1-9.

Adejuyitan, J. A., Abioye, A. O., Otunola, E. T., \& Oyewole, Y. (2012). An evaluation of some properties of baobab fruit powder and ogi mixes. Transnational Journal of Science and Technology, 2(7), 91-102.

Almustafa, K. A. A. (2003). The Industrial and Nutritional Utilization of Baobab pulp (Adansonia digitata L.).

Assogbadjo, A. E., Glèlè Kakaï, R., Chadare, F. J., Thomson, L., Kyndt, T., Sinsin, B., \& Van Damme, P. (2008a). Folk classification, perception, and preferences of baobab products in West Africa: Consequences for species conservation and improvement. Economic Botany, 62(1), 74-84. http://doi.org/10.1007/s12231-007-9003-6.

Assogbadjo, A. E., Chadare, F. J., Kakaï, R. G., Fandohan, B., \& Baidu-Forson, J. J. (2012b). Variation in biochemical composition of baobab (Adansonia digitata) pulp, leaves and seeds in relation to soil types and tree provenances. Agriculture, Ecosystems and Environment, 157(July 2016), 94-99. http://doi.org/10.1016/j.agee.2012.01.021.

Atta. B. M., \& El-Shenawi, G. M. (2013). Functional properties and In-vitro vitro digestibility of bitter orange ( Citrus aurantium ) seed flour. Merit Research Journal Of Agricultural Science and Soil Sciences, 1(3), $42-47$.

Besco, E., Braccioli, E., Vertuani, S., Ziosi, P., Brazzo, F., Bruni, R., ... Manfredini, S. (2007). The use of photochemiluminescence for the measurement of the integral antioxidant capacity of baobab products. Food Chemistry, 102(4), 1352-1356. http://doi.org/10.1016/j.foodchem.2006.05.067.

Caluwé, E. De, \& Damme, P. Van. (2010). Adansonia digitata L . - A review of traditional uses , phytochemistry 
and pharmacology. African Focus, 23(1), 11-51.

Donkor, A., Addae, D., \& Kpoanu, J. (2014). Antioxidant Enrichment of Baobab Fruit Pulp Treated with Oil Extracted from the Seeds. Food and Nutrition ..., 5, 328-333. http://dx.doi.org/10.4236/fns.2014.54039

Eltayeb, A. R. S. M., Ali, A. O., Abou-arab, A., \& Abu-salem, F. M. (2011). Chemical composition and functional properties of flour and protein isolate extracted from Bambara groundnut ( Vigna subterranean ). African Journal of Biotechnology, 5(2), 82-90.

Fagbohun, A. A., Ikokoh, P. P., Afolayan, M. O., Olajide, O. O., Fatokun, O. A., \& Akanji, F. T. (2012). Chemical Composition and Anti-Oxidant Capacity of the Fruit Pulp of Adansonia digitata L., 8(3), 165-172.

Gebauer, J., El-Siddig, K., \& Ebert, G. (2002). Baobab ( Adansonia digitata L .): A Review on a Multipurpose Tree with Promising Future in the Sudan. Gartenbauwissenschaft, 67(4), 155-160.

Gruenwald. J., \& Galizia, M. (2005). Market Brief in the Euro- pean Union for Selected Natural Ingredients Derived from Native Species, Adansonia digitata L. Baobab," In The United Nations Conference on Trade and Develop-ment (UNCTAD) BioTrade Initiative/BioTrade Facilita-tion Programme (BTFP) UNCTAD/DITC/TED.

Ibrahima, C., Didier, M., Max, R., Pascal, D., Benjamin, Y., \& Renaud, B. (2013). Biochemical and nutritional properties of baobab pulp from endemic species of Madagascar and the African mainland. African Journal of Agricultural, 8(47), 6046-6054. http://doi.org/10.5897/AJAR12.1231.

Kaboré Donatien, Hagretou, S.-L., Brehima, D., Compaore, C. S., Dicko, M. H., \& Jakobsen, M. (2011). A review of baobab (Adansonia digitata) products: Effect of processing techniques, medicinal properties and uses. African Journal of Food Science, 5(16), 833-844. http://doi.org/10.5897/AJFSX11.004

Kamatou, G. P. P., Vermaak, I., \& Viljoen, a. M. (2011). An updated review of Adansonia digitata: A commercially important African tree. South African Journal of Botany, 77(4), 908-919. http://doi.org/10.1016/j.sajb.2011.08.010

Kharate S. M \&Mulani .M.R. (2015). Morphological Variability of Elite Wild Population of Baobab (Adansonia digitata L.) in Aurangabad and Nanded Region of Maharashtra, India. International Journal of Current Research In Biosciences and Plant Biology, 1(5), 49-52.

Kisambira, A., Muyonga, J. H., Byaruhanga, Y. B., \& Tukamuhabwa, P. (2015). Composition and Functional Properties of Yam Bean ( Pachyrhizus spp .) Seed Flour. Food and Nutrition Science, 6, 736-746. http://dx.doi.org/10.4236/fns.2015.68076

Lamien-Meda, A., Lamien, C. E., Compaoré, M. M. Y., Meda, R. N. T., Kiendrebeogo, M., Zeba, B., ... Nacoulma, O. G. (2008). Polyphenol content and antioxidant activity of fourteen wild edible fruits from Burkina Faso. Molecules, 13(3), 581-594. http://doi.org/10.3390/molecules13030581

Magaia, T., Uamusse, A., Sjöholm, I., \& Skog, K. (2013b). Proximate analysis of five wild fruits of mozambique. The Scientific World Journal, 1-6. http://doi.org/10.1155/2013/601435

Magaia, T. (2012a). Nutritional Components in Selected Wild Fruits From Mozambique. Land university, Sweden.

Namratha, V., \& Sahithi, P. (2015). Baobab: A Review about “ The Tree of Life .” International Journal of Advanced Hebal Science and Technology, 1(1), 20-26.

Ndabikunze, B. K., Masambu, B. N., \& Tiisekwa, B. P. M. (2011). The production of jam from indigenous fruits using baobab (Adansonia digitata L .) powder as a substitute for commercial pectin. African Journal of Food Science, 5(March), 168-175.

Ndife, J., Ejikeme, C., \& Amaechi, N. (2010). Effect of oven drying on the functional and nutritional properties of whole egg and its components. International Journal of Food and Nutrition Science, 1(1), 254-257.

Obiageli, N. (2005). Effect of processing methods on nutrient, and functional properties of Jack bean(Canavalia ensiformis) and nutritive value of its blends with maize in rats. University of Nigeria,Nsukka.

Osman, M. A. (2004). Chemical and nutrient analysis of baobab (Adansonia digitata) fruit and seed protein solubility. Plant Foods for Human Nutrition, 59(1), 29-33. http://doi.org/10.1007/s11130-004-0034-1

Othman, O., Fabian, C., \& Lugwisha, E. (2014). Post Harvest Physicochemical Properties of Soursop (Annona Muricata L.) Fruits of Coast Region, Tanzania. Journal of Food and Nutrition Sciences, 2(5), 220. http://doi.org/10.11648/j.jfns.20140205.13 
Oyeleke, G. O., Olagunju, E. O., \& Ojo, A. (2012). Functional and Physicochemical Properties of Watermelon (Citrullus Lanatus ) Seed and Seed-Oil. IOSR Journal of Applied Chemistry, 2(2), 29-31. http://dx.doi.org/10.9790/5736-0222931

Rahul, J., Jain, M. K., Singh, S. P., Kamal, R. K., Anuradha, Naz, A., ... Mrityunjay, S. K. (2015). Adansonia digitata L. (baobab): a review of traditional information and taxonomic description. Asian Pacific Journal of Tropical Biomedicine, 5(1), 79-84. http://doi.org/10.1016/S2221-1691(15)30174-X

Santana, P., Huda, N., \& Yang, T. (2012). Technology for production of surimi powder and potential of applications. International Food Research Journal, 19(4), 1313-1323.

Sidibe, M., \& Williams, J. T. (2002). Baobab. Adansonia digitata L. Adansonia. International Centre for Underutilised Crops,Southampton,Uk.

Vikram, V. B., Ramesh, M. N., \& Prapulla, S. G. (2005). Thermal degradation kinetics of nutrients in orange juice heated by electromagnetic and conventional methods. Journal of Food Engineering, 69(1), 31-40. http://doi.org/10.1016/j.jfoodeng.2004.07.013

\section{Copyrights}

Copyright for this article is retained by the author(s), with first publication rights granted to the journal.

This is an open-access article distributed under the terms and conditions of the Creative Commons Attribution license (http://creativecommons.org/licenses/by/4.0/). 